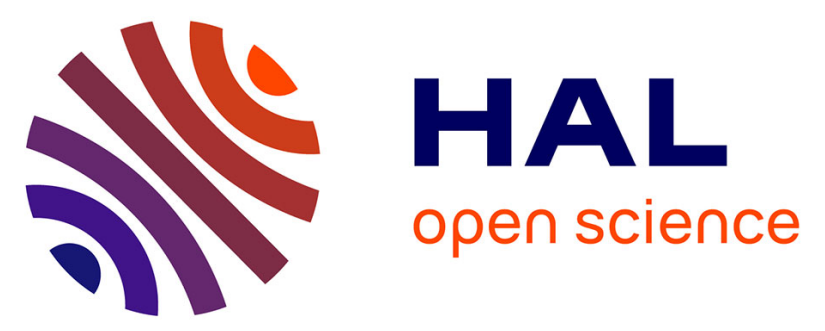

\title{
Social characterization of the medieval and modern population from Joué-lès-Tours (France): Contribution of oral health and diet
}

Valentin Miclon, M. Gaultier, C. Genies, Olivier Cotté, F. Yvernault, Estelle Herrscher

\section{To cite this version:}

Valentin Miclon, M. Gaultier, C. Genies, Olivier Cotté, F. Yvernault, et al.. Social characterization of the medieval and modern population from Joué-lès-Tours (France): Contribution of oral health and diet. Bulletins et Mémoires de la Société d'anthropologie de Paris, 2017, 10.1007/s13219-017-0192-y . hal-02131580

\section{HAL Id: hal-02131580 \\ https:/ /hal-univ-tours.archives-ouvertes.fr/hal-02131580}

Submitted on 16 May 2019

HAL is a multi-disciplinary open access archive for the deposit and dissemination of scientific research documents, whether they are published or not. The documents may come from teaching and research institutions in France or abroad, or from public or private research centers.
L'archive ouverte pluridisciplinaire HAL, est destinée au dépôt et à la diffusion de documents scientifiques de niveau recherche, publiés ou non, émanant des établissements d'enseignement et de recherche français ou étrangers, des laboratoires publics ou privés. 


\title{
Social Characterization of the Medieval and Modern Population from Joué-lès-Tours (France): Contribution of Oral Health and Diet
}

\author{
Caractérisation sociale de la population médiévale et moderne de Joué-lès-Tours (France) : \\ apports de l'état sanitaire bucco-dentaire et de l'alimentation
}

\author{
V. Miclon · M. Gaultier · C. Genies · O. Cotté · F. Yvernault · E. Herrscher \\ Reçu le 10 juillet 2017 ; accepté le 03 octobre 2017 \\ (C) Société d'Anthropologie de Paris et Lavoisier SAS 2017
}

\begin{abstract}
The social and cultural changes that occurred between the medieval and modern periods in urban contexts are well documented; however, those in rural contexts are less well understood. This research aims to bridge this gap by analysing changes in dietary practices and oral health conditions between the medieval and modern eras, and by identifying their relationship with the social status of individuals buried at the rural site of the church of Saint-Pierre and Saint-Paul in Joué-lès-Tours (Indre-et-Loire, France). The objectives of this study are to jointly analyse the isotopic data concerning the diet of 37 individuals and the osteological and archaeological data, and to tie these results in with local historical and archaeozoological data. While the burial
\end{abstract}

V. Miclon $(\bowtie) \cdot$ M. Gaultier $\cdot$ O. Cotté

Université de Tours, CNRS, CITERES UMR 7324,

37200 Tours, France

e-mail : valentin.miclon@etu.univ-tours.fr

\section{Gaultier}

Service de l'archéologie du département d'Indre-et-Loire, hôtel du département, place de la préfecture,

F-37927 Tours cedex 9, France

C. Genies

Éveha Tours, 13, rue des Granges-Galand,

F-37550 Saint-Avertin, France

O. Cotté

Institut national de recherches archéologiques préventives,

32, rue Delizy, F-93500 Pantin, France

\section{F. Yvernault}

Institut national de recherches archéologiques préventives,

148, avenue Maginot, F-37100 Tours, France

E. Herrscher

Aix-Marseille université,

CNRS, ministère de la Culture

et de la Communication, LAMPEA,

13094 Aix-en-Provence, France practices identified between the thirteenth and eighteenth centuries suggest social distinctions between groups of individuals, the study of $\operatorname{diet}\left(\delta^{13} \mathrm{C}\right.$ and $\left.\delta^{15} \mathrm{~N}\right)$ and the state of oral health point to a homogeneous social group characterized by the preferential consumption of pig meat, poultry and freshwater resources, and a degraded state of health. The available parochial registers and regional archaeozoological knowledge tend to confirm this hypothesis. This study confirms the relevance of the isotopic tool, which supplies dietary information to reinforce the archaeo-anthropological framework of interpretation, and also provides a critical examination of some of the criteria used to discuss the social composition of a set.

Keywords Social status · Oral health · Collagen · Carbon · Nitrogen $\cdot$ Historical

Résumé Si les modifications sociales et culturelles entre la société médiévale et moderne en contexte urbain sont bien documentées, celles en contexte rural le sont nettement moins. Cette recherche se propose de combler cette lacune, en analysant les modifications des pratiques alimentaires et des états de santé entre le Moyen Âge et l'époque moderne et en cernant ses relations avec le statut social des individus inhumés sur le site de l'église rurale SaintPierre-et-Saint-Paul de Joué-lès-Tours (Indre-et-Loire). Les objectifs visent une analyse conjointe des données isotopiques relatives à l'alimentation de 37 individus et des données ostéologiques et archéologiques et une mise en perspective des résultats avec les données archivistiques et archéozoologiques locales. Si les pratiques funéraires identifiées entre le $\mathrm{XIII}^{\mathrm{e}}$ et le $\mathrm{XVIII}^{\mathrm{e}}$ siècle laissent supposer des distinctions sociales entre les groupes d'individus, l'étude de l'alimentation $\left(\delta^{13} \mathrm{C}\right.$ et $\left.\delta^{15} \mathrm{~N}\right)$ et de l'état sanitaire buccodentaire plaide en faveur d'un groupe social homogène caractérisé par une consommation préférentielle de viande de porc, de volaille et de ressources d'eau douce, avec un 
état sanitaire dégradé. Les registres paroissiaux disponibles et les connaissances archéozoologiques régionales tendent à accréditer cette hypothèse. Cette étude confirme la pertinence de l'outil isotopique qui permet via l'alimentation de renforcer la grille de lecture archéoanthropologique, tout en apportant un regard critique sur certains critères utilisés pour discuter de la structuration sociale d'un ensemble.

Mots clés Statut social · État sanitaire $\cdot$ Collagène $\cdot$ Carbone $\cdot$ Azote $\cdot$ Historique

\section{Introduction}

The social characterization of individuals discovered in an archaeological context often comes up against different problems, making the exercise particularly delicate. Indeed, while the development of archaeological and anthropological methods improves our understanding of the management of funerary areas, and reveals clusters of deceased individuals within the population [1], the analysis and understanding of these phenomena, in relation to the reality experienced by the population, are confronted with the perception and cultural norms of society and of the people who had to face death individually and collectively [2].

The integration of aspects linked to the world of the living, rather than to the world of the dead, and especially to aspects with close connections to the social structure, such as dietary practices, can now provide essential information for the characterization of archaeological populations. In fact, they are the result of the close relationship between biological imperatives, resource availability, individual preferences and social norms $[3,4]$. Although textual, iconographic and archaeological sources provide ample insights into the dietary practices of medieval populations, these archives leave some aspects in the dark, including the dietary habits of rural populations [5-8]. The development of methods to study diet at an individual level offered the opportunity to improve our knowledge of the food practices of past societies using a comparative intra- and inter-site approach [9]. The analysis of the isotopic ratios of bone collagen carbon and nitrogen is invaluable as it reveals the dietary habits of the last 10 years of life of each of the subjects [10], thus expanding their archaeological identity. Surprisingly, the application of this method to the study of medieval and modern populations remains marginal in France [11-13]:

The use of these analyses therefore presents a twofold challenge:

- documenting food practices neglected by textual sources;
- integrating these data with existing data for different scales of analysis between the individual and the region in order to better characterize the population under study.

Using a sample of 37 individuals from a well-documented archaeological context, this study proposes to compare osteological data, including age and sex estimation and an assessment of dental health, to diet, by analysing the isotopic ratios of carbon and nitrogen in bone collagen. The results obtained will then be linked to the archeozoological data of Touraine and the study of parish registers.

\section{Medieval diet in Touraine, the contribution of archeozoology}

Several archeozoological studies have been carried out on the animal remains from the city of Tours as part of academic work, but also during preventive archeology excavations. Based on archaeological sources, the meat-based food of the inhabitants of Tours is well known since at least the Gallo-Roman period [14]. Despite several preventive excavations in rural areas, the rural diet is less well understood due to a deficient corpus. The analysis of the bone remains from medieval and modern Tours does not show a particularly marked regional character. As in most other cities across the kingdom, beef is largely dominant. Like in the rest of Europe during the medieval and modern periods, there is a gradual decrease in pork in favour of beef and sheep due to a new interest in speculative breeding $[15,16]$. Although major trends can be identified, the proportions of this triad (cattle, pig and sheep), and the composition of the wildlife spectrum vary, sometimes to a large degree, depending on the context and period in question. The social environment has a major impact on meat supply choices. The use of pig meat, particularly that of piglets, is a characteristic feature of the richest social groups. Indeed, the count's residency of the 11th and 12th centuries [7] and Saint-Julien's Abbey in the 14th century [8] are marked by a quantitatively and qualitatively high supply of pork. The kitchens of the count's residence also yielded a wide diversity and a slightly higher proportion of game birds, characteristic of seigneurial food. While lay lords preferred large game (deer and wild boar) and large birds (e.g., swans, cranes), ecclesiastical circles preferred small game, such as the hare [8]. It is also important to note that, for these privileged environments, the most meat-rich pieces are quantitatively the most important. Most of them come from animals raised specifically for meat and slaughtered when they reached their optimum weight. Besides these very specific contexts, more modest sites, such as the house of a craftsman or merchant in the 16th century, show a much simpler and much less varied food profile. For this kind of 
habitat, most of the meat supply is beef and the consumed pieces are of medium to low quality for the period [8].

\section{Materials and methods}

\section{The site}

The site of the church of Saint-Pierre and Saint-Paul is located in the town of Joué-lès-Tours, $5 \mathrm{~km}$ southwest of the historical centre of the city of Tours, in the department of Indre-et-Loire (Fig. 1). It was discovered during preventive excavations carried out by a team comprising members of the archaeological service of the Indre-et-Loire department (Sadil) and the French National Institute for Preventive Archaeological Research (INRAP), under the direction of Pierre Papin. The aim of the excavation was to study a rural Christian sanctuary that became the centre of a parish town during the medieval period. This excavation revealed the evolution of the sanctuary and the management of the dead over a long period of time, as the chronology of the site extends from the 7th to the 18th centuries. The archaeological operation revealed three periods of funerary occupation (Fig. 2):

- the first period (7th-11th centuries) is defined by the existence of a building with a nave surrounded by a funerary area. During this period, the building was not intended to accommodate the deceased, as only one individual from this chronological phase was discovered in ecclesia, suggesting that this man benefitted from special status within the community;

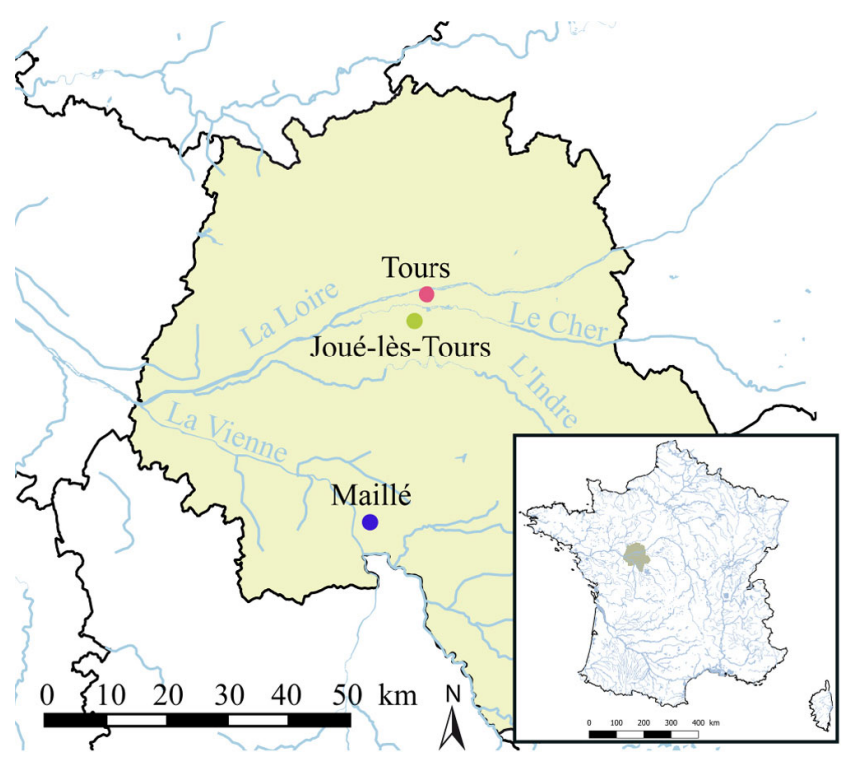

Fig. 1 Location of the studied archaeological site / Localisation du site étudié
- the period between the end of the 11th and the beginning of the 13th centuries is marked by major architectural (the addition of an apse, a north chapel and a south transept) and funerary changes, since no burial from this period was discovered, suggesting a restructuring of the cemetery topography beyond the boundaries of the excavation;

- from the second half of the 13th century, within the limits of the excavation, burials were installed in different sections of the building. No burial from this period was discovered outside the church due to the restriction of the cemetery to the west, outside the excavated area. This phase is also characterized by a diversification of funerary practices, with the appearance of well-ordered tombs (anthropomorphic formations, funerary stone, stretcher), alongside more modest tombs. Grave goods also appear in some cases, such as the presence of precious metal rings (copper alloy, silver and gold) and funerary pots. The analysis of the impregnations on the internal surfaces of the funerary pots suggests the use of incense probably from India or Ceylon. An initial anthropological study of the subjects from this period revealed that almost $80 \%$ of them were adults and that out of the 30 individuals whose sex could be determined, the presence of 16 men and 14 women showed no marked disparity in sex distribution [17].

The analysis of burial frequency revealed a much lower rate in the northern chapel, which, together with the presence of an individual buried with its head pointing towards the east (potentially a priest [18]), suggests that the area was reserved for a particular group of the population. Elsewhere in the edifice privileged burials (described above) contrast with more modest burials.

\section{Sample}

As part of this research, a new osteological study, as well as an analysis of the isotopic ratios of carbon and nitrogen of bone collagen, was carried out on 37 individuals from this site. The selection of these individuals was based on a set of archaeological factors: topographical (specific location in the building, orientation of the deceased), material (funerary architecture, presence of special grave goods: funerary pots, gold or copper rings, rosary beads), chronological (known and precise dating of individuals covering the period) and osteological (good representation of the number of observable teeth; adult individuals whose sex can be reliably estimated).

Three groups were defined as follows:

- the first encompasses seven individuals present in a space that seems reserved for a small number of subjects: "the northern chapel". In this study, these individuals will be grouped under this name; 


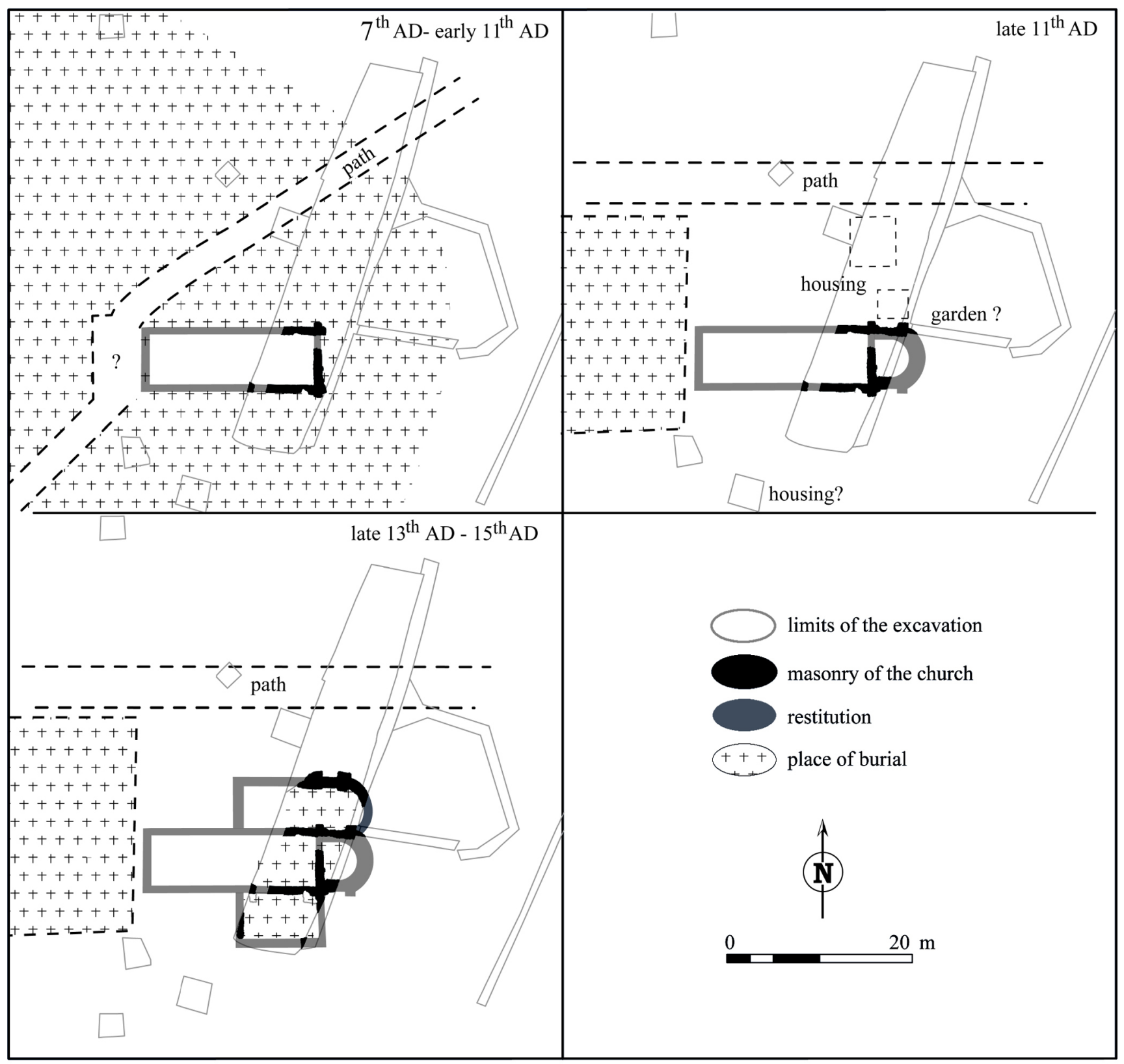

Fig. 2 Maps showing an overview of the topographic evolution of the site of Joué-lès-Tours from the 10th to the 15th centuries, modified from Papin et al. [17] / Plans synthétiques de l'évolution topographique du site de Joué-lès-Tours du $x^{\mathrm{e}}$ au Xv $\mathrm{v}^{\mathrm{e}}$ siècle, modifiés d'après Papin et al. [17]

- the second consists of individuals buried outside the northern chapel. Their funerary treatment suggests a privileged status (anthropomorphic formations, funerary stone, stretcher, funerary pots or precious metal rings). The adjective "privileged" will be used here to indicate the fourteen individuals belonging to this group;

- the last includes 16 subjects buried in "simple" tombs within the nave or the southern transept, which contrast with those of the two preceding groups as no particular funeral treatment was reserved for them. In this work, this group will be labelled as "Others".
These 37 individuals can be divided into three distinct chronological groups. A "Medieval" group including the 11 individuals from between the 13th and 15th centuries. Another "Modern" group encompasses the 22 subjects attributed with precision to the period between the 16th and the 18 th centuries. A third set "Imprecise dating" includes four individuals who could not be reliably assigned to either of these periods (Table 1).

Measurements of the isotopic carbon and nitrogen ratios of these individuals were compared with those obtained from a group of animals (six cattle, five goats, seven pigs, 
three fowl and one horse) from the Maillé sites of "Villiers" and "La Roche" (Table 2). This site was chosen as the source of the archeozoological corpus as it provides well-dated structures and presents the most similarities with the Jouélès-Tours site: rural context, chronological contemporaneity, geographical proximity.

\section{Osteological methods}

Sex estimation was based on probabilistic sex diagnosis [19]. A probability threshold of 0.95 was required for validation of the diagnosis.

The age-at-death estimation of the individuals was made by studying the morphology of the auricular surface of the ilium according to the method elaborated by Schmitt [20]. These estimations were occasionally complemented by observations of distinctive ossification characteristics, such as the sternal end of the clavicle and the iliac crest [21], and those related to dental development.

\section{Dental health}

Teeth are very resistant to diagenetic processes, which means that they are conserved where bones are generally not preserved. They are also the only hard and mineralized elements of the skeleton exposed to the environment through contact with food, and their structure is strongly dependent on genetics [22]. Different health indicators of the buccal

Table 1 Chronological and social distribution of the studied individuals / Distribution chronologique et sociale des individus étudiés

\begin{tabular}{|lllll|}
\hline Groups & Medieval (13th-15th) & Imprecise dating (13th-18th) & Modern (16th-18th) & Total \\
\hline The northern chapel & 2 & 4 & 1 & 7 \\
Privileged & 2 & 0 & 12 & 14 \\
Others & 7 & 0 & 9 & 16 \\
Total & 11 & 4 & 22 & 37 \\
\hline
\end{tabular}

Table 2 Taxonomic, chronological, and biogeochemical data of 22 bones from the archeozoological corpus / Données taxinomiques, chronologiques et biogéochimiques des 22 ossements animaux de Maillé

\begin{tabular}{|c|c|c|c|c|c|c|c|c|}
\hline Sample & Species & Period & Yield (mg/g) & $\% \mathrm{C}$ & $\% \mathbf{N}$ & $\mathbf{C} / \mathbf{N}$ & $\delta^{13} \mathrm{C}(\%)$ & $\delta^{15} \mathrm{~N}(\%)$ \\
\hline MA_F01 & Cattle & Medieval & 64.1 & 39.5 & 14.4 & 3.2 & -21.9 & 7.6 \\
\hline MA_F02 & Cattle & Medieval & 187.7 & 41.8 & 15.4 & 3.2 & -21.4 & 4.5 \\
\hline MA_F03 & Cattle & Medieval & 180.0 & 42.0 & 15.4 & 3.2 & -21.7 & 10.2 \\
\hline MA_F04 & Cattle & Medieval & 50.9 & 42.7 & 15.6 & 3.2 & -21.5 & 6.2 \\
\hline MA_F05 & Cattle & Modern & 145.3 & 42.0 & 15.3 & 3.2 & -21.3 & 7.2 \\
\hline MA_F06 & Cattle & Modern & 54.0 & 40.1 & 14.6 & 3.2 & -21.7 & 5.3 \\
\hline MA_F07 & Goat & Medieval & 35.5 & 40.3 & 14.6 & 3.2 & -21.0 & 4.6 \\
\hline MA_F08 & Goat & Medieval & 183.3 & 42.2 & 15.4 & 3.2 & -21.5 & 5.7 \\
\hline MA_F09 & Goat & Medieval & 33.9 & 40.0 & 14.5 & 3.2 & -21.5 & 6.5 \\
\hline MA_F10 & Goat & Modern & 35.1 & 34.3 & 11.4 & 3.5 & -22.0 & 8.2 \\
\hline MA_F11 & Goat & Modern & 55.3 & 39.9 & 14.3 & 3.3 & -21.2 & 6.9 \\
\hline MA_F12 & Horse & Medieval & 27.1 & 36.8 & 13.2 & 3.2 & -22.3 & 6.1 \\
\hline MA_F13 & Domestic fowl & Medieval & 162.5 & 42.3 & 15.4 & 3.2 & -20.1 & 8.7 \\
\hline MA_F14 & Domestic fowl & Medieval & 172.6 & 42.4 & 15.2 & 3.2 & -20.3 & 8.7 \\
\hline MA_F15 & $\begin{array}{l}\text { Domestic fowl } \\
\text { or goose }\end{array}$ & Medieval & 172.4 & 41.2 & 14.9 & 3.2 & -20.4 & 7.1 \\
\hline MA_F16 & Pig & Medieval & 24.4 & 36.9 & 13.5 & 3.2 & -21.3 & 8.1 \\
\hline MA_F17 & Pig & Medieval & 155.9 & 35.9 & 13.0 & 3.2 & -21.1 & 6.1 \\
\hline MA_F18 & Pig & Medieval & 168.1 & 43.1 & 15.8 & 3.2 & -20.8 & 8.7 \\
\hline MA_F19 & Pig & Medieval & 71.8 & 42.1 & 15.3 & 3.2 & -20.7 & 7.5 \\
\hline MA_F20 & Pig & Medieval & 50.4 & 41.5 & 15.3 & 3.2 & -21.2 & 10.6 \\
\hline MA_F21 & Pig & Modern & 49.0 & 38.4 & 14.0 & 3.2 & -20.6 & 7.3 \\
\hline MA_F22 & Pig & Medieval & 154.1 & 41.0 & 15.0 & 3.2 & -20.4 & 5.6 \\
\hline
\end{tabular}


sphere are related to diet and are also relatively easy to observe. They are assessed using various well-established evaluation methods. In this study, the caries and ante mortem losses were counted and wear, tartar and periodontosis were evaluated using a rating system derived from that proposed by Brothwell [23]. For each of these criteria, an index was established, corresponding either to the number of teeth or dental sites showing the feature relative to the total number of teeth, or dental sites for which the criterion is observable (caries and ante mortem losses), or relative to the average of the stages of each tooth for which the criterion is observable per individual (wear, tartar and periodontosis). These individual indices were used if, and only if, at least eight observations were possible, that is, eight teeth for caries, wear, dental calculus, periodontosis or eight observable dental sites (ante mortem losses) per individual (Table 3).

\section{A non-specific stress indicator: linear enamel hypoplasia}

Amelogenesis may be disturbed by stress resulting in defects in consistency or color in the form of lines or bands on the tooth surface [24]. These markers are "non-specific stress markers" [25] because they reflect various disturbances (e.g., physiological, environmental, dietary) experienced by the individual during childhood while the tooth is forming. These disturbances can be very informative for determining intra-population differences in order to assess whether they are correlated with particular socioeconomic groups [26].

During this work, hypoplasias were observed under lowangled light and macroscopically counted on the vestibular surface of each tooth. An index was then established corresponding to the number of hypoplasias observed relative to the number of teeth in a suitable state of preservation for recording these marks (Table 3 ).

\section{Isotopic analysis}

This study builds on research carried out over the last 30 years on the evolution of stable isotope ratios of carbon and nitrogen $\left({ }^{13} \mathrm{C} /{ }^{12} \mathrm{C}\right.$ and ${ }^{15} \mathrm{~N} /{ }^{14} \mathrm{~N}$, respectively) in the biological tissues of organisms from different environments [27]. The $\delta^{13} \mathrm{C}$ and $\delta^{15} \mathrm{~N}$ values of plants are reflected in those of consumers from the upper trophic levels, accompanied by heavy isotope enrichment at each level of the food web [28]. The increase in the isotopic ratios between plantbased food and bone collagen in herbivores is estimated to be $\sim 5 \%$ for carbon and 3-5\%o for nitrogen [28]. There is also an enrichment of $\sim 1 \%$ for $\delta^{13} \mathrm{C}$ and of $3-5 \%$ for $\delta^{15} \mathrm{~N}$ $[29,30]$ between the bone collagen of prey and that of consumers. Collagen enrichment in ${ }^{15} \mathrm{~N}$ depends mainly on the length of the food chain. In aquatic environments, food chains are longer than on land, leading to higher ${ }^{15} \mathrm{~N}$ enrich- ment, and hence higher $\delta^{15} \mathrm{~N}$ values for high-trophic consumers. This is also true for $\delta^{13} \mathrm{C}$ values.

Different factors can modify the local isotopic values of plants at the bottom of the trophic network and are reflected in the tissues of organisms of successive trophic levels [31], even within a radius of $<100 \mathrm{~km} \mathrm{[32].} \mathrm{Insofar} \mathrm{as} \mathrm{the} \mathrm{isotopic}$ approach consists in evaluating which food poles are closest to the isotopic values of human subjects, it is essential to take into consideration a local and contemporary faunal reference system for the human population studied.

The isotopic ratios of carbon and nitrogen in bone collagen largely reflect the protein content of the diet due to its polypeptide nature. Protein synthesis is, in fact, a result of the reuse of the ingested amino acids [29]. It is generally accepted that these relationships provide information about the average diet during the last 10 years of an individual's life [10].

In this study, collagen extraction was carried out at the UMR 7269 LAMPEA in Aix-en-Provence. The protocol used was defined by Longin [33] and modified by Bocherens [34]. The collagen samples were analysed by the IsoAnalytical laboratory (Crewe, Cheshire, UK), which carried out the elemental and isotopic measurements with an isotopic mass spectrometer (EA-IRMS). The equipment used was a Europa Scientific 20-20 isotope mass spectrometer coupled with an automated elemental analyser. An internal beef liver standard (IA-R042) was used for which the isotopic content was calibrated from standards provided by the international atomic energy agency: IAEA-CH-6 (sucrose, $\delta^{13} \mathrm{C}=-10.43 \%$ ) and IAEA-N-1 (ammonium sulfate, $\delta^{15} \mathrm{~N}=0.40 \%$ ). The analytical accuracy obtained from the repeated analysis of the internal laboratory standard was $0.11 \%$ for the $\delta^{13} \mathrm{C}$ values and $0.04 \%$ for the $\delta^{15} \mathrm{~N}$ values.

Statistical tests were carried out using R software (3.2.3). The nonparametric Wilcoxon and Kruskal-Wallis tests were used: the former for comparing two series and the latter for series of three (Table 4).

\section{Results}

\section{Osteological data}

We were able to estimate the sex on 23 of the 37 individuals studied. This sample is composed of 12 men and 11 women, along with 14 individuals of undetermined sex (Table 3 ). The estimation of the age at death of all the individuals in our corpus covers a period of several decades. The relationship between this factor and food and health could not be evaluated (Table 3).

No statistically significant differences were found in distributions of the different oral health indicators, sex, socioeconomic groups or chronological periods (Table 4). 


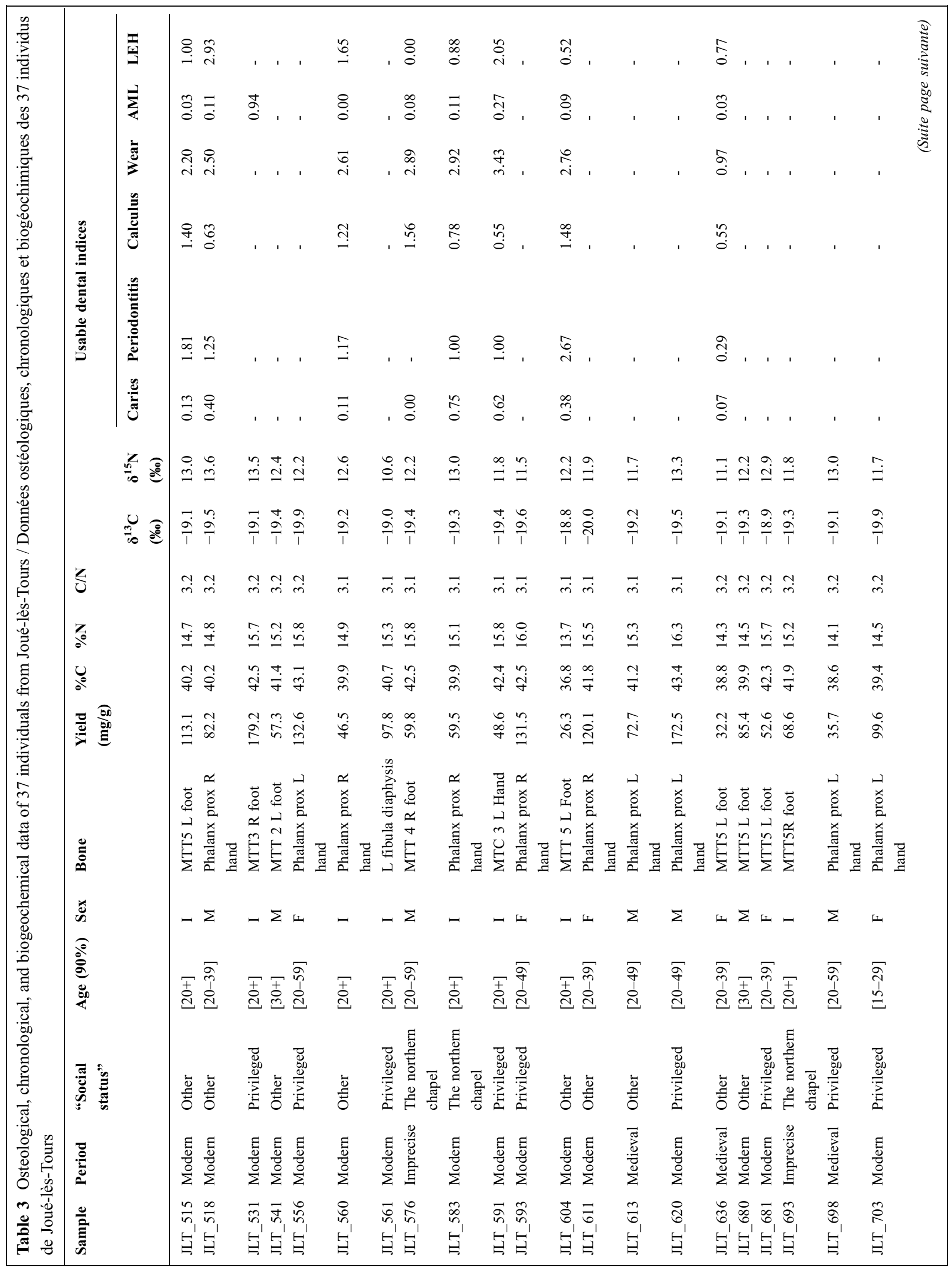




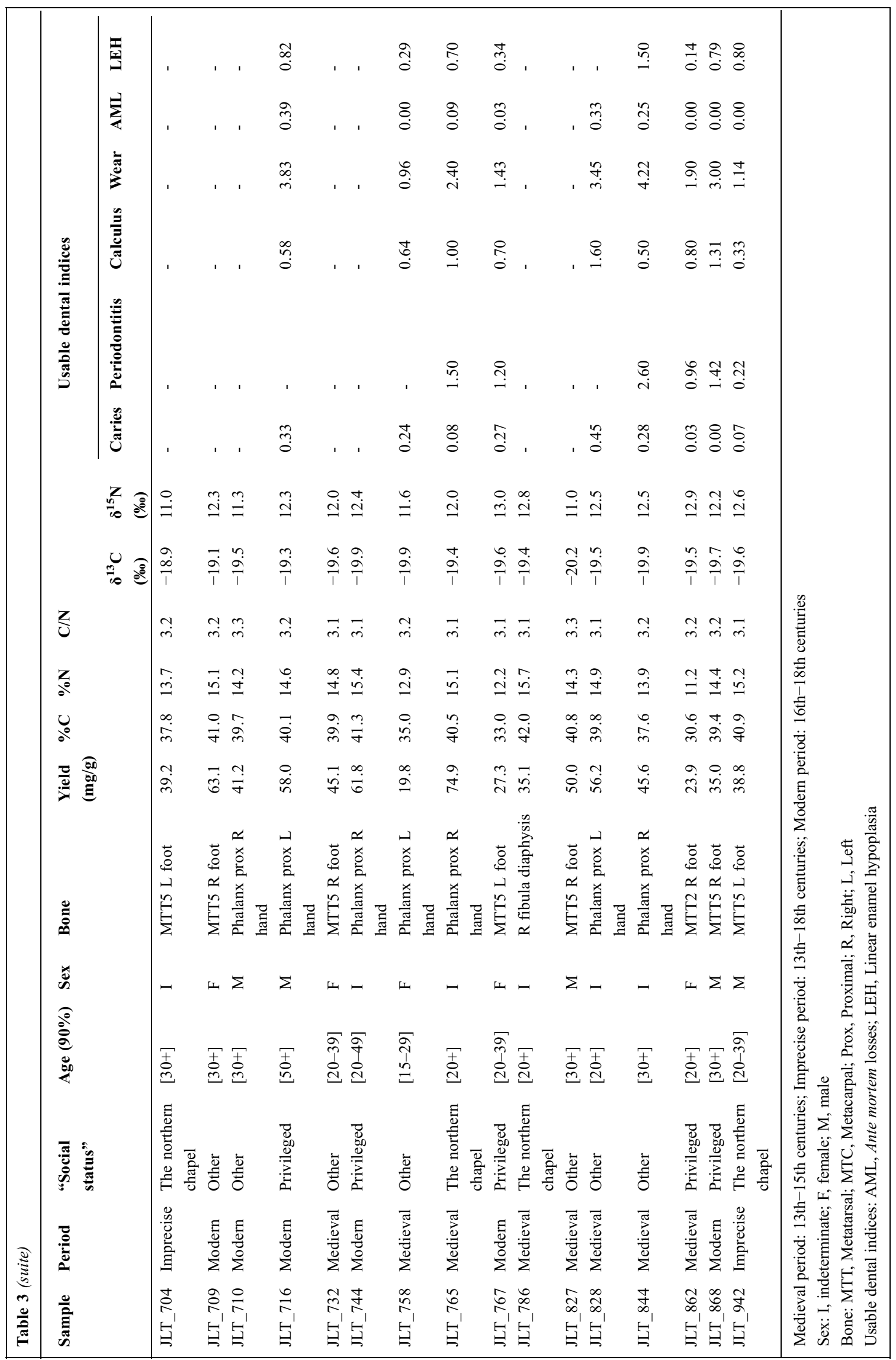


Table 4 Distribution of different oral health and isotopic indicators by sex, chronological series and socio-economic groups / Distributions des différents indicateurs sanitaires bucco-dentaires et isotopiques selon le sexe, les périodes chronologiques et les groupes socio-économiques

\begin{tabular}{|c|c|c|c|c|c|c|c|c|c|c|}
\hline \multirow[t]{2}{*}{ Indicator } & \multicolumn{3}{|l|}{ Sex } & \multicolumn{3}{|l|}{ Period } & \multicolumn{4}{|c|}{ "Social status" groups } \\
\hline & $\mathbf{n M}$ & $\mathbf{n F}$ & $p^{\mathbf{a}}$ & nMed & nMod & $p^{\mathbf{a}}$ & nPrivileged & $\begin{array}{l}\text { nNorthern } \\
\text { chapel }\end{array}$ & nOthers & $p^{\mathbf{b}}$ \\
\hline Calculus & 4 & 4 & 0.886 & 6 & 9 & 0.637 & 5 & 4 & 8 & 0.841 \\
\hline AML & 4 & 4 & 0.642 & 6 & 10 & 0.358 & 6 & 4 & 8 & 0.845 \\
\hline Periodontitis & 2 & 3 & 1.000 & 4 & 8 & 0.671 & 4 & 3 & 6 & 0.349 \\
\hline Wear & 4 & 4 & 0.114 & 6 & 9 & 0.456 & 5 & 4 & 8 & 0.759 \\
\hline Caries & 4 & 4 & 0.559 & 6 & 9 & 0.272 & 5 & 4 & 8 & 0.614 \\
\hline LEH & 4 & 4 & 0.343 & 5 & 9 & 0.112 & 5 & 4 & 7 & 0.511 \\
\hline$\delta^{13} \mathrm{C}$ & 11 & 11 & 0.409 & 11 & 22 & 0.442 & 14 & 7 & 16 & 0.679 \\
\hline$\delta^{15} \mathrm{~N}$ & 11 & 11 & 0.598 & 11 & 22 & 0.358 & 14 & 7 & 16 & 0.577 \\
\hline \multicolumn{11}{|c|}{ 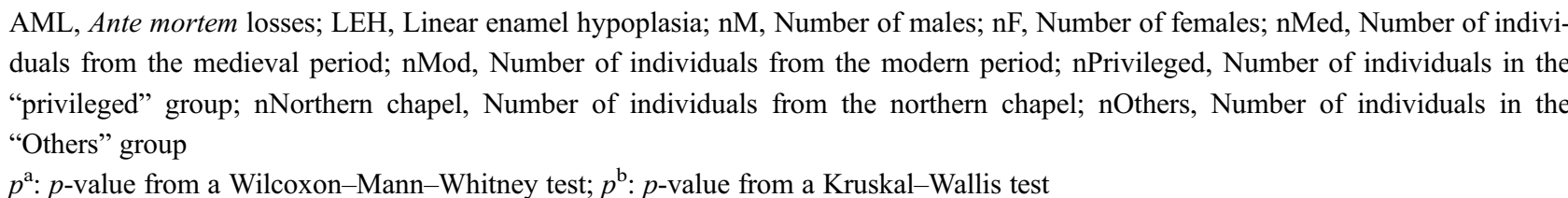 } \\
\hline
\end{tabular}

The number of decayed teeth in relation to the total number of teeth, for which this criterion is observable, is comparable to those of various historical European populations. The rate of carious lesions in the Joué-lès-Tours sample (23.2\%) falls within the observed range for these periods, but is towards the upper limits (Fig. 3) $[9,11,22,35,36]$.

Therefore, the studied sample shows a degraded health status compared to other contemporaneous populations, at least with regard to these lesions. It appears likely, given the high frequency of caries in the Joué-lès-Tours population, that individuals regularly consumed carbohydrates.

Only 1 of the 16 individuals, for whom the index was established on at least 8 teeth, was free of linear enamel hypoplasia. Thus, for the corpus studied, the prevalence of these lesions is $93.8 \%$. This is particularly high when compared to the medieval and modern adult populations described in the literature (Fig. 4) $[9,11,25,37]$. Despite the small number of studied individuals, this result suggests that the individuals in our corpus experienced a set of non-specific intense stresses, and is indicative of difficult living conditions during all the periods considered, irrespective of sex or social status.

\section{Isotopic data}

The atomic $\mathrm{C} / \mathrm{N}$ ratio is a tool used to verify the preservation of the collagen of a sample. DeNiro [38] has shown that this ratio must be between 2.9 and 3.6 for archaeological bones. The relative amounts of carbon and nitrogen in each sample can also be used as a control. It is generally accepted that for archaeological remains, these must be greater than $30 \%$ and $11 \%$, respectively [39]. Finally, the extracted yield of collagen must be $>10 \mathrm{mg} / \mathrm{g}$ [39].

The 59 analysed (human and faunal) samples satisfied the criteria for the validation of collagen preservation. All the indicators fell within the limits indicating that all the samples are neither degraded nor contaminated (Tables 2, 3, extraction yield $>10 \mathrm{mg} / \mathrm{g}, \% \mathrm{C}>30, \% \mathrm{~N}>11$ and $\mathrm{C} / \mathrm{N}$ between 2.9 and 3.6) $[38,39]$.

$\delta^{13} \mathrm{C}$ values for fauna $(n=22)$ range from -22.3 to $-20.1 \%$, and those of $\delta^{15} \mathrm{~N}$, from 4.5 to $10.6 \%$ (Table 2, Fig. 5). The $\delta^{13} \mathrm{C}$ values for fauna correspond to the expected values for terrestrial animals in a temperate environment dominated by $\mathrm{C}_{3}$ type plants [27]. There is ${ }^{13} \mathrm{C}$ and ${ }^{15} \mathrm{~N}$ enrichment between herbivores and omnivores $(+0.9 \%$ in ${ }^{13} \mathrm{C}$ and $+1.2 \%$ in ${ }^{15} \mathrm{~N}$ ), which the Wilcoxon test shows to be statistically significant $(p<0.05$ and $p=0.05$, respectively). Heavy isotope enrichment, although significant, is less than that observed between two consecutive trophic levels, indicating a low assimilation of animal proteins in the diet of omnivorous animals [12].

The human $\delta^{13} \mathrm{C}$ values $(n=37)$ range from -20.2 to $-18.8 \%$ o (mean $\pm \mathrm{SD}=-19.4 \pm 0.3 \%$ ), and those of $\delta^{15} \mathrm{~N}$ between 10.6 and 13.6\%o (12.2 $\pm 0.7 \%$ ) (Table 3, Fig. 5). The results appear to be homogeneous within the human population $\left(\Delta\left(\delta^{13} \mathrm{C}_{\max }-\delta^{13} \mathrm{C}_{\min }\right)=1.4 \%\right.$ and $\left.\Delta\left(\delta^{15} \mathrm{~N}_{\max }-\delta^{15} \mathrm{~N}_{\min }\right)=3.0 \%\right)$. The $\delta^{13} \mathrm{C}$ values for humans also correspond to the expected values for an environment dominated by $\mathrm{C}_{3}$ plants [27]. Individuals from the northern chapel $(n=7)$ show $\delta^{13} \mathrm{C}$ values between -19.6 and $-18.9 \%$ 


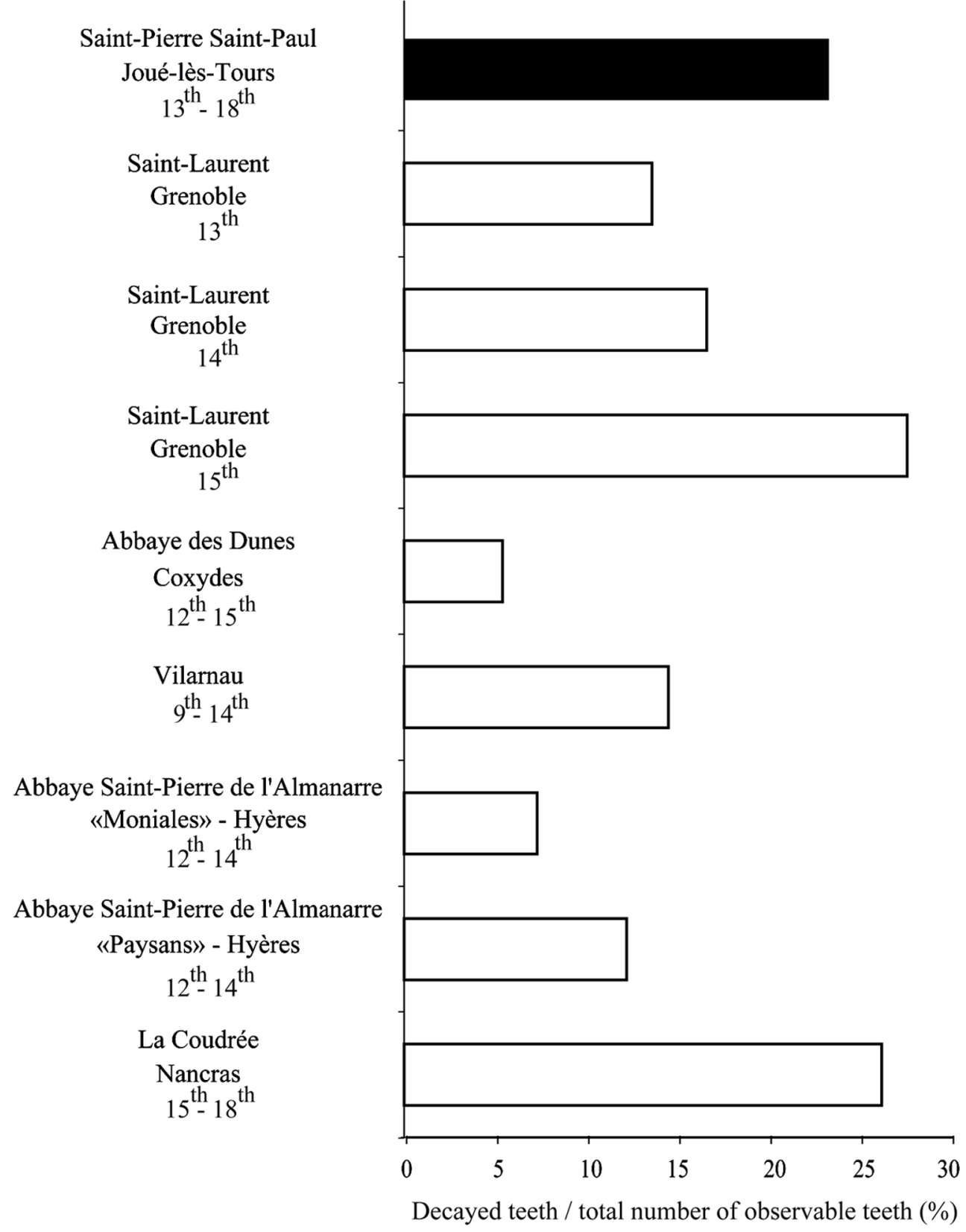

Fig. 3 Proportion (\%) of decayed teeth per total number of observable teeth for various historical populations: SPSP: SaintPierre-et-Saint-Paul de Joué-lès-Tours; SLT: Saint-Laurent de Grenoble [11]; AbD: abbaye des Dunes de Coxydes [9]; Vil: Vilarnau [22]; SPAm: Saint-Pierre de l'Almanarre — "Nuns" [35]; SPAp: Saint-Pierre de l'Almanarre — "Peasants" [35]; LCou: La coudrée at Nancras [36]; Proportion (\%) de dents cariées par rapport au nombre total de dents observables de différentes populations historiques : SPSP : Saint-Pierre-et-Saint-Paul de Joué-lès-Tours ; SLT : Saint-Laurent de Grenoble [11] ; AbD : abbaye des Dunes de Coxydes [9] ; Vil : Vilarnau [22] ; SPAm : Saint-Pierre de l'Almanarre — « Moniales » [35] ; SPAp : Saint-Pierre de l'Almanarre — « Paysans » [35]; LCou : La coudrée à Nancras [36]

$\left(-19.3 \pm 0.2 \%\right.$ ) and $\delta^{15} \mathrm{~N}$ values between 11.0 and $13.0 \%$ $(12.2 \pm 0.6 \%$ ). The individuals from the "privileged" group $(n=14)$ have $\delta^{13} \mathrm{C}$ values between -19.9 and $-18.9 \%$ $\left(-19.5 \pm 0.3 \%\right.$ o and $\delta^{15} \mathrm{~N}$ values between 10.6 and $13.5 \%$ $(12.4 \pm 0.8 \%$ o). Finally, individuals in the "others" group
( $n=16$ ) have $\delta^{13} \mathrm{C}$ values ranging from -20.2 to $-18.8 \%$ $\left(-19.4 \pm 0.4 \%\right.$ ) and $\delta^{15} \mathrm{~N}$ values ranging from 11.0 to $13.6 \%$ $(12.1 \pm 0.7 \%$ ). Individuals from the medieval period $(n=11)$ have $\delta^{13} \mathrm{C}$ values between -20.2 and $-19.1 \%$ $\left(-19.5 \pm 0.3 \%\right.$ ) and $\delta^{15} \mathrm{~N}$ values between 11.0 and $13.0 \%$ 


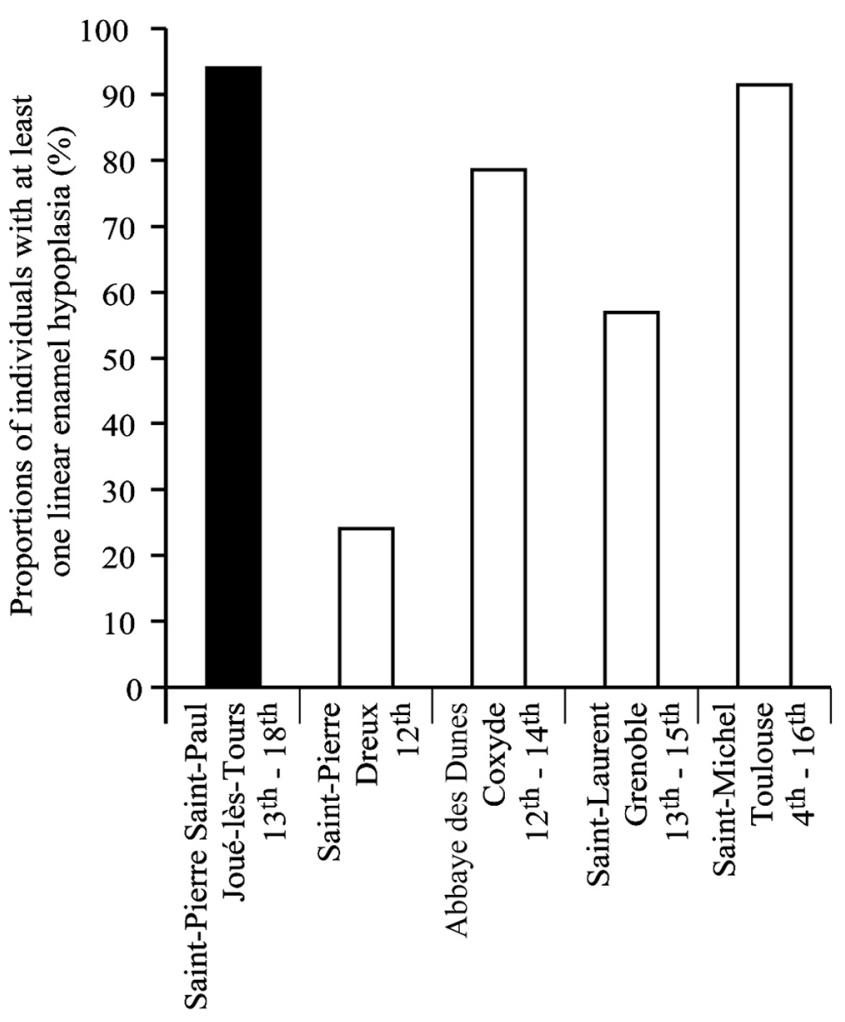

Fig. 4 Proportions of individuals with at least one linear enamel hypoplasia from various historical populations $[9,11,25,37]$ / Proportions des individus porteurs d'au moins une hypoplasie linéaire de l'émail dentaire au sein de différentes populations historiques $[9,11,25,37]$

$(12.1 \pm 0.7 \%$ ). Those from the modern period $(n=22)$ have $\delta^{13} \mathrm{C}$ values ranging from -20.0 to $-18.8 \%$ o $(-19.4 \pm 0.3 \%$ ) and $\delta^{15} \mathrm{~N}$ values between 10.6 and $13.6 \%$ (12.4 $\pm 0.7 \%$ ).

\section{Discussion}

\section{Diet reconstitution}

The comparison of the isotopic data of human subjects with those obtained for the fauna from Maillé shows that a human diet consisting exclusively of herbivores is incompatible with the results obtained, as $\Delta^{13} \mathrm{C}_{\text {Humans-Herbivores }}=2.2 \%$ and $\Delta^{15} \mathrm{~N}_{\text {Humans-Herbivores }}=5.6 \%$ (Fig. 5). On the other hand, a human diet composed mainly of omnivores could theoretically explain the values obtained within the population as a whole because $\Delta^{13} \mathrm{C}_{\text {Humans-Omnivores }}=1.3 \%$ and $\Delta{ }^{15} \mathrm{~N}_{\text {Humans-Omnivores }}=4.4 \%$ (Fig. 5). While this is the most parsimonious explanation, it is not the only possible hypothesis. Indeed, the consumption of young unweaned herbivores [40], or of herbivores fed with plants fertilized with manure [41], and the consumption of aquatic resources [28], could also explain the values obtained for humans.
Indeed, data from the literature indicate that medieval marine fish (whiting, skate, ling, haddock, herring and pleuronectiformes) discovered in a Dominican priory in East Yorkshire (probably from the North Sea) have $\delta^{13} \mathrm{C}$ values between -16.1 and $-11.8 \%$ and $\delta^{15} \mathrm{~N}$ values between 10.1 and $17.2 \%$ o $(n=19$; [42]). Given the isotopic values of these species, the combined consumption of marine resources and herbivore meat could explain the significant isotopic enrichments calculated solely on the basis of a difference between herbivores and humans.

Although freshwater fish have $\delta^{13} \mathrm{C}$ values that are generally closer to terrestrial values, these species display very wide variability, even within the same hydrographic set. For instance, Katzenberg and Weber [43] obtained (eight taxa, $n=21) \delta^{13} \mathrm{C}$ values between -24.6 and $-12.9 \%$ and between 7.3 and $13.7 \%$ for $\delta^{15} \mathrm{~N}$ for the same lake. Similarly, Dufour et al [44] showed that high variations exist between different hydrographic sets for $\delta^{13} \mathrm{C}$ and $\delta^{15} \mathrm{~N}$ values, including those for the same taxon. These authors revealed that for seven different taxa from four lakes, $\delta^{13} \mathrm{C}$ values varied from -32.2 to $-19.8 \%$ and from 7.0 to $14.9 \%$ for $\delta^{15} \mathrm{~N}$.

Thus, in Joué-lès-Tours, the consumption of aquatic resources, whether marine or freshwater, is consistent with the results obtained for the isotopes under investigation. Moreover, considering the fact that lifestyles were strongly dictated by the Church during this period, it seems plausible that these individuals would have consumed fish. Indeed, the village is located at the heart of a river system known to have been exploited, as examples of contemporaneous fisheries in the region have been previously described [45]. A study of the archival sources carried out before this work also indicates the presence, at least during the modern period, of a fishpond within the presbytery adjoining the church, which attests to the availability and proximity of this resource in the landscape [17]. Finally, the presence of fish during the High Middle Ages on the site of Joué-lès-Tours was revealed fortuitously by carpological analysis [17]. Although the fish remains have not been taxonomically determined, archival data tend to support the hypothesis of the consumption of freshwater resources. Mixed consumption of pork, poultry and freshwater resources is the most likely scenario to account for the distribution of the isotopic ratios obtained for the 13th-18th centuries. The isotopic characterization of the archaeological freshwater fish of the region will make it possible to verify this hypothesis.

\section{Diet and health}

The state of oral health appears degraded for the observed criteria compared to other contemporaneous populations, and homogeneous within our corpus for all the studied parameters. This observation is consistent with individuals 


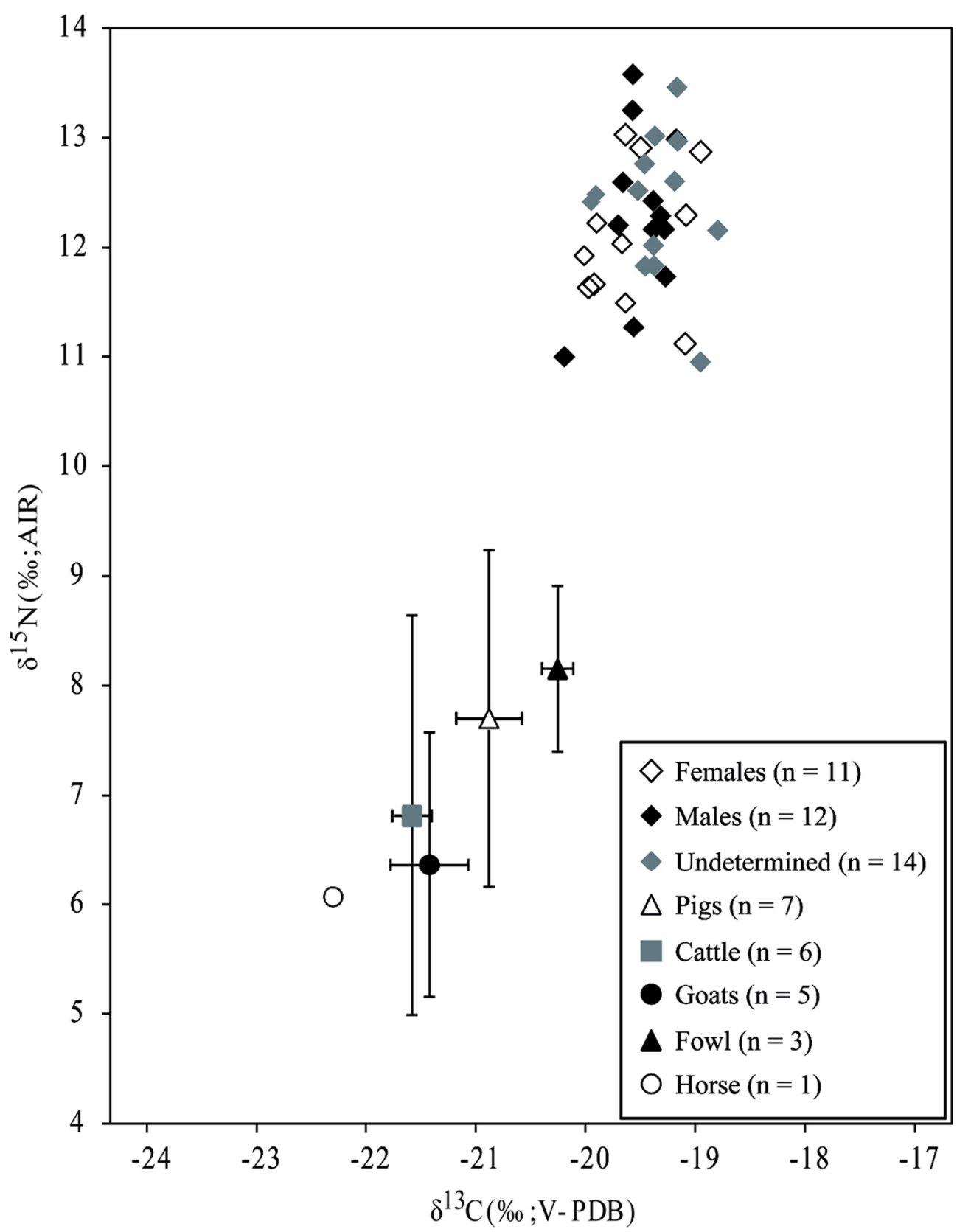

Fig. 5 Isotope ratios $\left(\delta^{15} \mathrm{~N}\right.$ and $\left.\delta^{13} \mathrm{C}\right)$ of humans and local contemporaneous animal corpus $( \pm 1 \sigma) /$ Rapports isotopiques $\left(\delta^{15} \mathrm{~N}\right.$ et $\left.\delta^{13} \mathrm{C}\right)$ des humains et de la faune régionale $( \pm 1 \sigma)$

belonging to a group within a close-knit social and cultural context, as is the marked similarity observed between the subjects with regard to non-specific stress markers, such as linear enamel hypoplasia.

The isotopic and health data resulting from this study, and the invariability of the results obtained for the different chronological periods considered here, calls into question the previously accepted postulate that there was a rupture between the medieval and modern periods in terms of foodrelated behaviour. Our results also raise questions concerning the relationship between the social status and health of medieval and modern populations, as in Joué-lès-Tours the likelihood of belonging to an affluent group is not inconsistent with poor health.

\section{Diet and social status}

The Kruskal-Wallis test comparing the isotopic values for the different proposed social groups did not reveal any significant differences between them (Table 4). As the proposed social groups have similar isotopic signatures, the comparison of the alimentary resources consumed by men and 
women was carried out on the whole corpus (a set of 23 individuals of known sex, all periods combined). The Wilcoxon test also confirmed the homogeneity of the isotopic values of carbon and nitrogen with regard to sex $(p>0.05)$.

The social groups studied here were proposed on the basis of archaeological criteria. However, our results, concerning food or health, showed no difference between these groups (Table 4). Two hypotheses should thus be considered; either the proposed criteria do not correspond to a real social structure, or these groups do not have distinct dietary practices (perceptible by biochemical analysis) or different health status.

\section{Diet and chronological phases}

In the absence of differences in isotopic signatures between men and women, as well as between the proposed social groups (Table 4), well-dated individuals from our corpus were compared and divided into two major chronological phases: the medieval period (13th-15th) and the modern period (16th-18th), in order to determine whether changes occurred over time.

According to the Wilcoxon test carried out for the $\delta^{13} \mathrm{C}$ and $\delta^{15} \mathrm{~N}$ variables $(p>0.05)$, the isotopic values do not differ significantly between these two periods for the individuals buried at the site of the Saint-Pierre-et-Saint-Paul
Church in Joué-lès-Tours. Therefore, there would be no change in protein intake between the two chronological phases considered.

\section{Study of the parochial registers of Joué-lès-Tours}

The parochial registers of Joué-lès-Tours contain 7,452 death certificates from 1670 to 1792 , which represents an average of 61 burials per year in the parish. The study of these documents makes it possible to compare the recruitment of each funerary area and thus to analyse whether they conform to biological or social criteria. The last mention of a burial inside the building dates from 1775 .

In the registers, the profession of the deceased or of their parents is indicated for 3,086 individuals. To compare the representation of the different social groups within the funerary areas, the different professions were divided into different social categories: "highest" (noble, clergy, bourgeois), "medium+" (master craftsman, merchant, member of the army, clerk, etc.), "medium" (husbandman), "medium" (winegrower, craftsman), "lowest" (domestic, daily worker).

For individuals for whom the burial site and the occupation (their own or their relatives) are known (Fig. 6), only 1\% of the total cemetery population belongs to the highest social category, that is, 55 individuals, as opposed to $12.5 \%$ in the church (77 people). The highest social

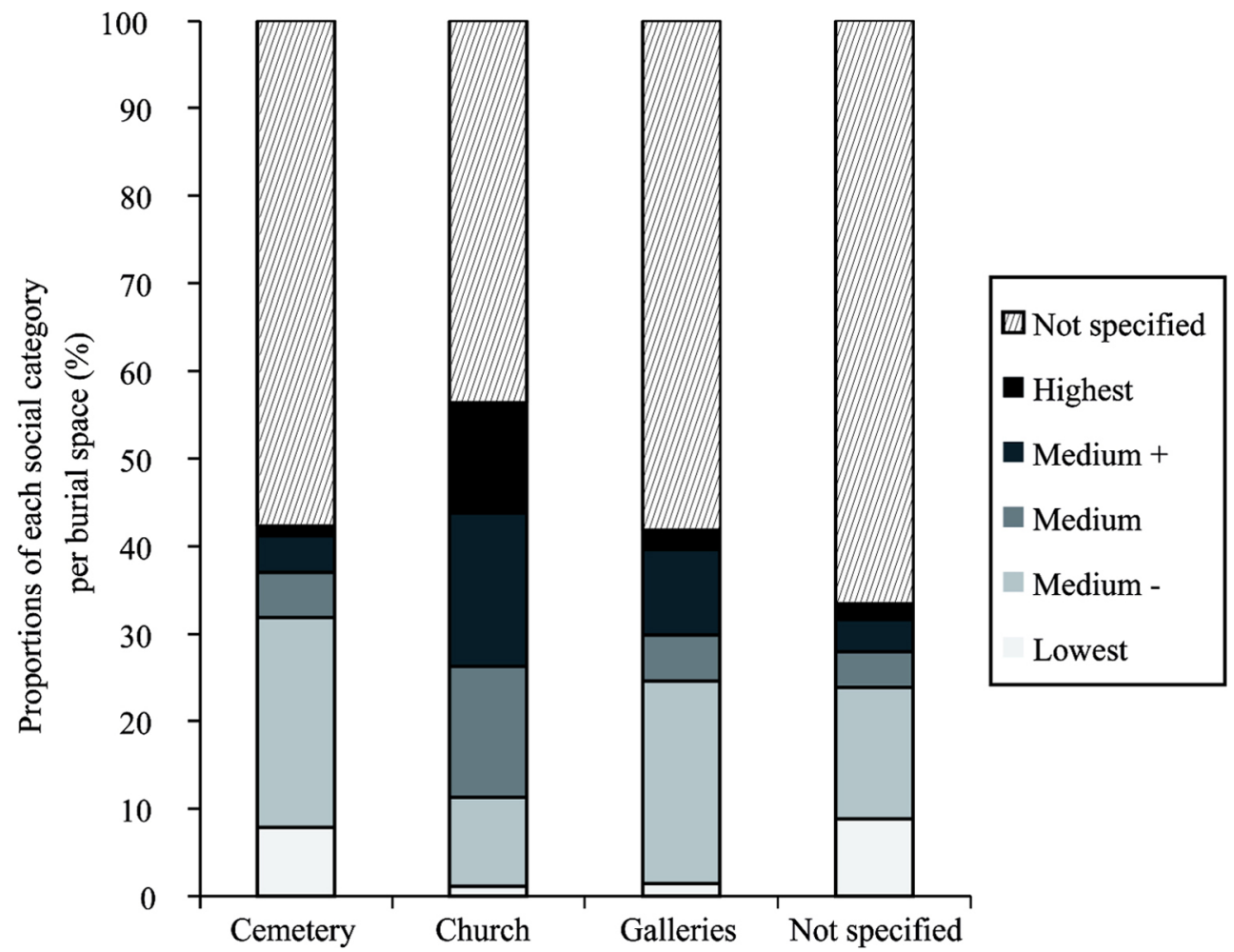

Fig. 6 Proportions of death certificates in the parish registers (1670-1792) according to social class and place of burial / Proportions des actes de décès dans les registres paroissiaux (1670-1792) selon la catégorie sociale et le lieu d'inhumation 
categories are preferentially buried inside the church. Nevertheless, this is not an exclusive rule and the majority of burials inside the church belong to the middle classes. Thus, of the 532 burials in the church, there are 80 labourers, 39 merchants, and 25 winegrowers. Yet, nothing rules out the presence of a certain number of representatives from "important families" of local proprietors and farmers among the intermediate categories. Categories considered to be inferior are also mentioned, such as six domestic servants. However, these individuals were in the service of those with an influence over the community (lord, lieutenant of the king, etc.).

With regard to age distribution, the registers were very informative (Fig. 7). Children from birth to 10 years old represent about $20 \%$ of the burials within the church ( $36.5 \%$ in the cemetery). The 10 - to 19 -year-old group represents $3 \%$ of the burials in the church, compared with $5.8 \%$ in the cemetery. The presence of adults between the ages of 20 and 49 years is almost constant for the church (25.8\%) and the cemetery (27.6\%). On the other hand, people over 50 represent $30.6 \%$ of those buried in the church, compared to $22.8 \%$ of those buried in the cemetery. Therefore, the adult age groups, especially those over the age of 50 years, are better represented within the church.
For the church population, the average age at death for those over 20 years is 51.2 years. This is within the range proposed by Maillard [46], who established that the "norm" in Touraine for this period was between 50 and 55 years of age. Nevertheless, it is relatively low within this range. It is important to recall that this range is based on parishes in their entirety and not only on the privileged groups studied here. In addition, Joués parochial registers indicate that for the entire population, the average age at death for individuals who have reached 20 years is 48 years, which is below this "norm" [17]. Consequently, these documents seem to support the hypotheses proposed on the basis of archaeological, osteological and isotopic findings; namely, that the population buried in the church had a privileged status within the community and a lower life expectancy compared to other parishes in the region - a fact that could be related to the observed degraded health of the individuals.

\section{Conclusion}

Joué-lès-Tours holds a prominent place in the knowledge and understanding of medieval and modern rural societies. This site, with its high density and long duration of funerary

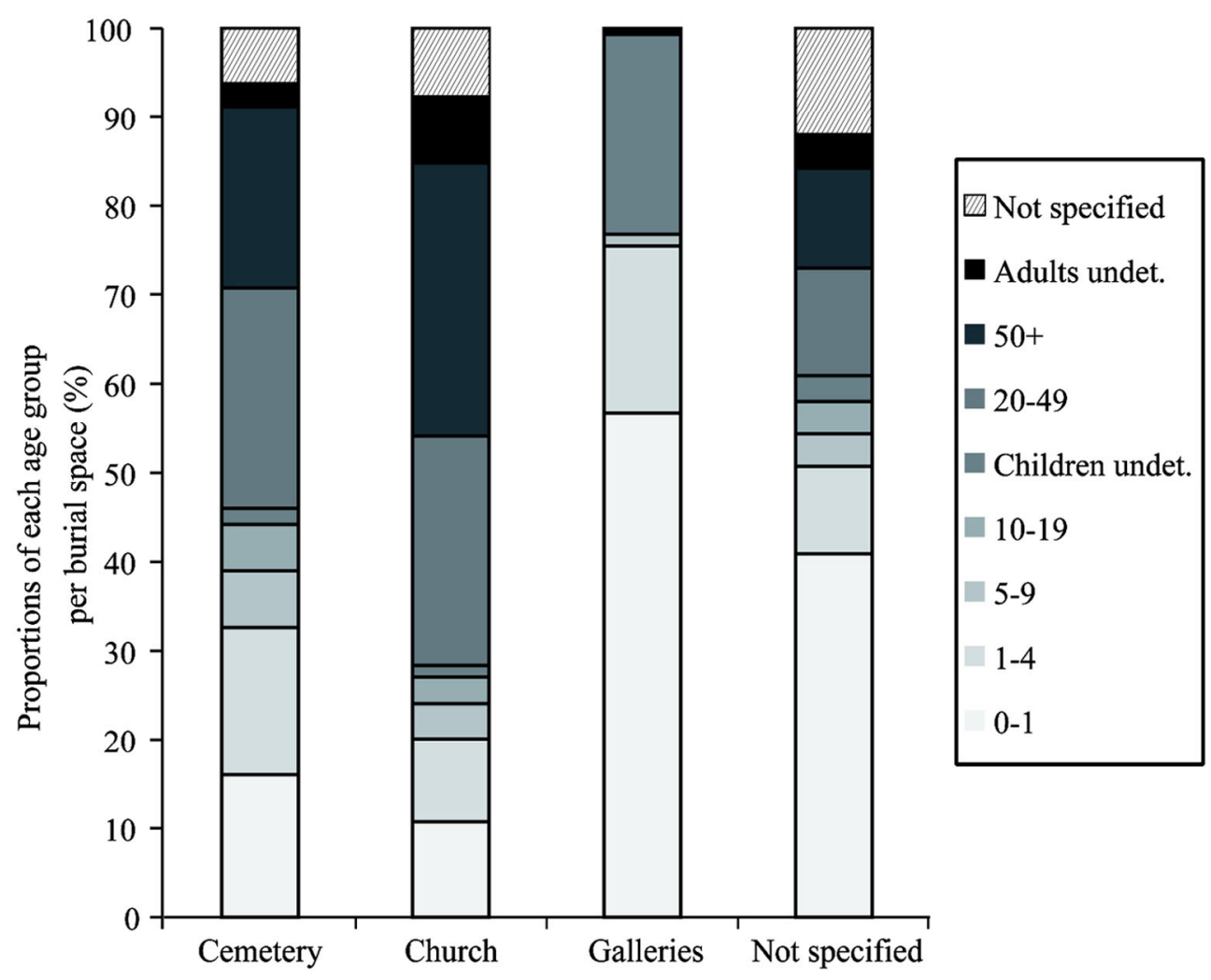

Fig. 7 Proportions of death certificates in the parish registers (1670-1792) according to age and place of burial / Proportions des actes de décès dans les registres paroissiaux (1670-1792) selon l'âge et le lieu d'inhumation 
practices, underwent a multidisciplinary study and provided a foundation of knowledge on which this work could be based. The objective was to clarify the complex relationship between the diet, social status and health of a rural medieval population by reducing the scale of analysis down to the level of the individual.

The biochemical and anthropological analyses applied here clarified this relationship by using a sample of 37 individuals buried between the 13th and 18th centuries in the church of Saint-Pierre-et-Saint-Paul of Joué-lès-Tours, and comparing them with a set of 22 contemporaneous animals from Maillé. The human corpus was based on the ability of each individual to provide maximum information about social status, oral health, age and sex. It was also essential that the corpus included individuals from various time frames across the whole studied period.

The isotopic study of the medieval and modern humans of Joué-lès-Tours and the contemporaneous local fauna showed that the population presents an unexpected diet for this period compared to information from textual sources about rural dietary practices [5]. It seems that the meat component of the diet focused mainly on pork and poultry, in addition to aquatic resources, probably freshwater. Within our sample, this diet appears to be very homogeneous, at least with regard to the protein content, which is similar for men and women, and for all the chronological periods and groups studied. Indeed, our corpus is composed of individuals predominantly buried in a privileged space inside the church. In addition, the community is located near Tours, and certainly had strong links with the city. Pork consumption was the main marker of social distinction in this city during these periods $[7,8]$, and it is possible that this model was reproduced by the surrounding communities.

This study provides new elements for our understanding of medieval and modern society in Touraine, but also raises other questions in relation to the site, and the region. Thus, for Joué-lès-Tours, only new analyses of the population buried outside the building can confirm or invalidate the model that we propose - namely, the presence inside the church of a homogeneous group of socially privileged individuals with a specific diet.

At a regional level, similar analyses of different sites would improve our understanding of medieval and modern food practices, including the impact of the availability of resources on different scales, social and religious practices, and the type of human settlement, on the diet of these periods.

Acknowledgments The authors thank Pierre Papin of the archaeological service of the department of Indre-et-Loire and Gwenael Roy of the French National Institute for Preventive Archaeological Research (INRAP) for providing archaeological material. The authors also thank Steve Broo- kes from IsoAnalytical Ltd. for the spectrometric analyses, and Guy André and Leïa Mion from UMR 7269 LAMPEA for their valuable assistance in sample preparation. The authors also thank Inga Topolnicki from the University of Sydney, Isabelle Josseau-Montagne from the University of Tours and Louise Byrne for editing the English version of the manuscript. The authors thank the anonymous reviewers for their careful reading and their valuable comments and suggestions to improve the quality of the paper.

Conflict of interest: None.

\section{References}

1. Castex D, Courtaud P, Duday H (2011) Le regroupement des morts : genèse et diversité archéologique. Maison des sciences de l'homme d'Aquitaine, Bordeaux, France, $306 \mathrm{p}$

2. Ariès $P$ (1977) L'homme devant la mort. Éditions du Seuil, Paris, France, $642 \mathrm{p}$

3. Lévi-Strauss C (1964-1971) Mythologiques. Plon, Paris, France, 4 vol.

4. Poulain JP (2008) Manger aujourd'hui : attitudes, normes et pratiques. Privat, Toulouse, France, $235 \mathrm{p}$

5. Laurioux B (2002) Manger au Moyen Âge : pratiques et discours alimentaires en Europe aux $\mathrm{XIV}^{\mathrm{e}}$ et $\mathrm{XV}^{\mathrm{e}}$ siècles. Hachette, Paris, France, $299 \mathrm{p}$

6. Meyzie P (2010) L'alimentation en Europe à l'époque moderne. Armand Colin, Paris, France, $288 \mathrm{p}$

7. Genies C (2014) Le régime carné. In: Galinié H (éd) Des thermes de l'Est de Caesarodunum au château de Tours : le site 3. FERACF, Tours, pp 143

8. Cotté $\mathrm{O}(2008)$ La société urbaine à Tours et l'animal $\left(\mathrm{XIV}^{\mathrm{e}}-\mathrm{XVII}{ }^{\mathrm{e}}\right.$ s.) : approche archéozoologique. Thèse de doctorat, université François-Rabelais de Tours, 2 vol, $830 \mathrm{p}$

9. Polet C (1996) Essai de paléonutrition appliqué à trois populations médiévales belges. Thèse de doctorat, Université libre de Bruxelles, $182 \mathrm{p}$

10. Hedges REM, Clement JG, Thomas CDL, et al (2007) Collagen turnover in the adult femoral mid-shaft: modeled from anthropogenic radiocarbon tracer measurements. Am J Phys Anthropol $133: 808-16$

11. Herrscher E (2001) Contribution de l'analyse paléoépidémiologique et paléobiogéochimique à la connaissance de la santé et de l'alimentation à la fin du Moyen Âge, église Saint-Laurent de Grenoble $\left(\mathrm{XIII}^{\mathrm{e}}-\mathrm{XV}^{\mathrm{e}}\right.$ s., Isère, France). Thèse de doctorat, Muséum national d'histoire naturelle, Paris, France, 335 p

12. Herrscher E (2003) Alimentation d'une population historique, analyse des données isotopiques de la nécropole Saint-Laurent de Grenoble $\left(\mathrm{XIII}^{\mathrm{e}}-\mathrm{X}^{\mathrm{e}}\right.$ siècle, France). Bull Mem Soc Anthropol Paris 15:149-269

13. Carlier A, Hervieu P, Herrscher E (2014) Les habitudes alimentaires à l'époque moderne : contributions des analyses isotopiques. In: Nin N (éd) Aix en archéologie : 25 ans de découvertes. Snoeck, Heule, pp 457-9

14. Galinié H, Lorans É, Husi P, et al (2007) Tours antique et médiéval : lieux de vie, temps de la ville : 40 ans d'archéologie urbaine, FERACF, Tours, France, $440 \mathrm{p}+1 \mathrm{CD}$-Rom

15. Audoin-Rouzeau F (1995) Compter et mesurer les os animaux. Pour une histoire de l'élevage et de l'alimentation en Europe de l'Antiquité aux temps modernes. Histoire Mesure 10:277-312 
16. Clavel B (2001) L'animal dans l'alimentation médiévale et moderne en France du Nord ( $\mathrm{XIII}^{\mathrm{e}}-\mathrm{XVII}{ }^{\mathrm{e}}$ siècles). Rev Archeol Picardie 19:9-204

17. Papin P, Livet J, Vanhove C, et al (2013) Joué-lès-Tours (37). Places Victor-Hugo et François-Mitterrand. Origine et évolution d'un centre paroissial rural. Conseil général d'Indre-et-Loire, Inrap, DRAC/SRA Centre, Orléans, France, 4 vol., 1830 p

18. Lorans É, Husi P, Theureau C, et al (2006) Saint-Mexme de Chinon, $\mathrm{V}^{\mathrm{e}}-\mathrm{XX}^{\mathrm{e}}$ siècles. Éditions du CTHS, Paris, France, $598 \mathrm{p}$

19. Murail P, Bruzek J, Houët F, et al (2005) DSP: a tool for probabilistic sex diagnosis using worldwide variability in hip-bone measurements. Bull Mem Soc Anthropol Paris 17:167-76

20. Schmitt A (2005) Une nouvelle méthode pour estimer l'âge au décès des adultes à partir de la surface sacropelvienne iliaque. Bull Mem Soc Anthropol Paris 17:89-101

21. Webb PAO, Suchey JM (1985) Epiphyseal union of the anterior iliac crest and medial clavicle in a modern multiracial sample of American males and females. Am J Phys Anthropol 68:457-66

22. Esclassan R (2012) Étude des caries dentaires en fonction du sexe au sein d'individus adultes de la population médiévale $\left(\mathrm{IX}^{\mathrm{e}}-\mathrm{XV}^{\mathrm{e}}\right.$ siècles) de Vilarnau (Pyrénées-Orientales) et synthèse sur l'usure. Thèse de doctorat, université Toulouse-III-Paul-Sabatier, $249 \mathrm{p}$

23. Brothwell DR (1981) Digging up bones: the excavation, treatment, and study of human skeletal remains, Cornell University Press, Ithaca, New York, $208 \mathrm{p}$

24. Goodman AH, Armelagos GJ (1985) Factors affecting the distribution of enamel hypoplasias within the human permanent dentition. Am J Phys Anthropol 68:479-93

25. Castex D (1994) Mortalité, morbidité et gestion de l'espace funéraire au cours du haut Moyen Âge, contribution spécifique de l'anthropologie biologique. Thèse de doctorat, université Bordeaux-I, 2 vol, $500 \mathrm{p}$

26. Lewis M, Roberts C (1997) Growing pains: the interpretation of stress indicators. Int J Osteoarchaeol 7:581-6

27. Schoeninger MJ, DeNiro MJ (1984) Nitrogen and carbon isotopic composition of bone collagen from marine and terrestrial animals. Geochim Cosmochim Acta 48:625-39

28. Bocherens H (1999) Isotopes stables et reconstitution du régime alimentaire des hominidés fossiles : une revue. Bull Mem Soc Anthropol Paris 11:261-87

29. Ambrose SH, Norr L (1993) Experimental evidence for the relationship of the carbon isotope ratios of whole diet and dietary protein to those of bone collagen and carbonate. In: Lambert JB, Grupe G (eds) Prehistoric human bone. Springer, Berlin, Heidelberg, pp 1-37

30. Bocherens H, Drucker D (2003) Trophic level isotopic enrichment of carbon and nitrogen in bone collagen: case studies from recent and ancient terrestrial ecosystems. Int $\mathrm{J}$ Osteoarchaeol $13: 46-53$

31. Goude G, Fontugne M (2016) Carbon and nitrogen isotopic variability in bone collagen during the Neolithic period: influence of environmental factors and diet. J Archaeol Sci 70:117-31
32. Herrscher E, Le Bras-Goude G (2010) Southern French Neolithic populations: isotopic evidence for regional specificities in environment and diet. Am J Phys Anthropol 141:259-72

33. Longin R (1971) New method of collagen extraction for radiocarbon dating. Nature 230:241-2

34. Bocherens H, Fizet M, Mariotti A, et al (1991) Isotopic biogeochemistry $\left({ }^{13} \mathrm{C},{ }^{15} \mathrm{~N}\right)$ of fossil vertebrate collagen: application to the study of a past food web including Neanderthal man. J Hum Evol 20:481-92

35. Aubry M, Mafart B, Cherid A, et al (2001) Pathologie dentaire d'une population de moniales médiévales cisterciennes de l'abbaye Saint-Pierre de l'Almanarre ( $\mathrm{XIII}^{\mathrm{e}}-\mathrm{XIV}^{\mathrm{e}} \mathrm{s}$ s.). In: Hadjouis D, Mafart B (éds) La paléo-odontologie : analyses et méthodes d'étude. Paléoanthropologie et paléopathologie osseuse. ARTCOM', Paris, pp 138-51

36. Bédécarrats S, Souquet-Leroy I, Leroy F (2016) Caractérisation biologique et comportements funéraires d'une population rurale moderne - La " Coudrée », Nancras, Charente-Maritime (17). Bull Mem Soc Anthropol Paris 28(1 Suppl):8

37. Garcin V, Velemínský P, Trefný P, et al (2010) Dental health and lifestyle in four early mediaeval juvenile populations: comparisons between urban and rural individuals, and between coastal and inland settlements. HOMO 61:421-39

38. DeNiro MJ (1985) Postmortem preservation and alteration of in vivo bone collagen isotope ratios in relation to palaeodietary reconstruction. Nature 317:806-9

39. Van Klinken GJ (1999) Bone collagen quality indicators for palaeodietary and radiocarbon measurements. J Archaeol Sci 26:687-95

40. Hedges REM, Reynard LM (2007) Nitrogen isotopes and the trophic level of humans in archaeology. J Archaeol Sci 34:1240-51

41. Bogaard A, Heaton THE, Poulton P, et al (2007) The impact of manuring on nitrogen isotope ratios in cereals: archaeological implications for reconstruction of diet and crop management practices. J Archaeol Sci 34:335-43

42. Müldner G, Richards MP (2005) Fast or feast: reconstructing diet in later medieval England by stable isotope analysis. J Archaeol Sci 32:39-48

43. Katzenberg MA, Weber A (1999) Stable isotope ecology and palaeodiet in the Lake Baikal region of Siberia. J Archaeol Sci 26:651-9

44. Dufour E, Bocherens H, Mariotti A (1999) Palaeodietary implications of isotopic variability in Eurasian lacustrine fish. J Archaeol Sci 26:617-27

45. Noizet H (2007) La fabrique de la ville : espaces et sociétés à Tours, IV ${ }^{\mathrm{e}}-\mathrm{XIII}{ }^{\mathrm{e}}$ siècle. Publications de la Sorbonne, Paris, France, $504 \mathrm{p}$

46. Maillard B (1992) Les campagnes de Touraine au XVIII ${ }^{\mathrm{e}}$ siècle : étude d'histoire économique et sociale. PU Rennes, Rennes, France, $500 \mathrm{p}$ 